\title{
Analisa Kinerja pada Perencanaan TD-LTE ADVANCED Studi Kasus Kota Bandung
}

\author{
Hastruman*, Arfianto Fahmi, Uke Kurniawan Usman \\ Jurusan S1 Teknik Telekomunikasi, Fakultas Teknik Elektro, Universitas Telkom \\ *email : purusadihastruman97@gmail.com
}

\begin{abstract}
In LTE Advanced technology there are two methods used in the duplexing process, there are frequency division duplex (FDD) wherein this duplexing concept communication is divided based on the frequency and the other is time division duplex (TDD) where communication is divided based on the time. Duplexing using the TDD method has advantages of handling data-based services that the majority have Non-Guarantee Bit Rate (N-GBR) characteristics because most of these services do not require a minimum bit rate to be able to work and this is an advantages because nowadays people like to use data-based services. So in this LTE Advanced network planning using the TDD method, frequency $2300 \mathrm{MHz}$ for TDLTE advanced, and parameters that to be the main focus are throughputs, reference signal received power (RSRP), reference signal strength indicator (RSSI), carrier to interference noise ratio (CINR), and block error rate (BLER). And the result of the simulations from TDLTE Advanced planning are the mean of throughput value is 3,5 Mbps, mean of RSRP value is $-110,8 \mathrm{dBm}$, mean of RSSI value is $-72,36 \mathrm{dBm}$, mean of CINR value is 4,81 dB, and mean of BLER value is 0,07\%. Thus the use of time division duplexing method is not suitable to be implemented due to the fairly low value of the average throughput obtained.
\end{abstract}

Keywords - Duplexing, TDD, TD-LTE Advanced

\section{Pendahuluan}

Teknologi LTE Advanced memiliki dua metode duplexing di antaranya frequency division duplex (FDD) dan time division duplex (TDD) [1]. Pada saat ini mayoritas penyedia layanan menggunakan metode duplexing FDD, metode duplexing FDD membutuhkan sepasang frekuensi identik dalam proses komunikasinya, hal ini disebabkan karena komunikasi uplink dan komunikasi downlink dilakukan dalam frekuensi yang berbeda. Sementara metode duplexing TDD hanya membutuhkan sebuah kanal frekuensi untuk melakukan proses komunikasi, hal ini disebabkan karena metode duplexing TDD membagi komunikasi uplink dan komunikasi downlink berdasarkan alokasi waktu yang telah ditentukan [2].

Sehingga penerapan metode duplexing TDD dapat melakukan efisiensi dalam penggunaan spektrum frekuensi karena tidak diperlukannya frekuensi yang berpasangan (paired frequency), disamping itu dengan sifatnya yang asimetris operator dapat lebih leluasa dalam melakukan penyeimbangan beban trafik [3]. Walau demikian penerapan metode duplexing TDD memiliki kelemahan, yaitu dengan terdapatnya guard period metode duplexing TDD memiliki nilai delay yang lebih besar sehingga metode duplexing TDD lebih cocok untuk menangani layanan berbasis data. Hal ini dikarenakan layanan berbasis data mayoritas bersifat Non-Guarantee Bit Rate (N-GBR) karena layanan ini tidak membutuhkan bit rate minimum untuk dapat bekerja serta melakukan efisiensi frekuensi.

Pada simulasi ini dilakukan penerapan metode duplexing menggunakan TDD pada dua buah frekuensi yang berdekatan yakni dengan bandwidth sebesar $20 \mathrm{MHz}$ yang terletak pada frekuensi 2360-2380 MHz dan bandwidth $10 \mathrm{MHz}$ yang terletak pada frekuensi 2380-2390 $\mathrm{MHz}$ dengan area studi kasus Kota Bandung. 


\section{Tinjauan Pustaka}

\subsection{Konsep Time Division Duplexing (TDD)}

Time division duplex atau TDD merupakan salah satu metode duplexing yang terdapat pada teknologi LTE dimana pada metode duplexing ini komunikasi dibagi berdasarkan alokasi waktu yang telah ditentukan.

Konsep duplexing dengan metode TDD menggunakan frekuensi tunggal yang artinya proses uplink dan downlink dilakukan dalam frekuensi yang sama tetapi dipisahkan berdasarkan waktu [4]. Keuntungan penggunaan duplexing menggunakan metode TDD adalah transmisi data antara downlink dan uplink tidak simetris sehingga operator dapat mengalokasikan trafik sesuai kebutuhan. Hal ini sejalan dengan perkembangan layanan saat ini, dimana penggunaan komunikasi bergerak berkembang dalam hal layanan data dan teknologi LTE sudah mengimplementasikan konsep all-ip sehingga pengiriman data tetap akan berjalan dengan menggunakan metode FDD maupun TDD.

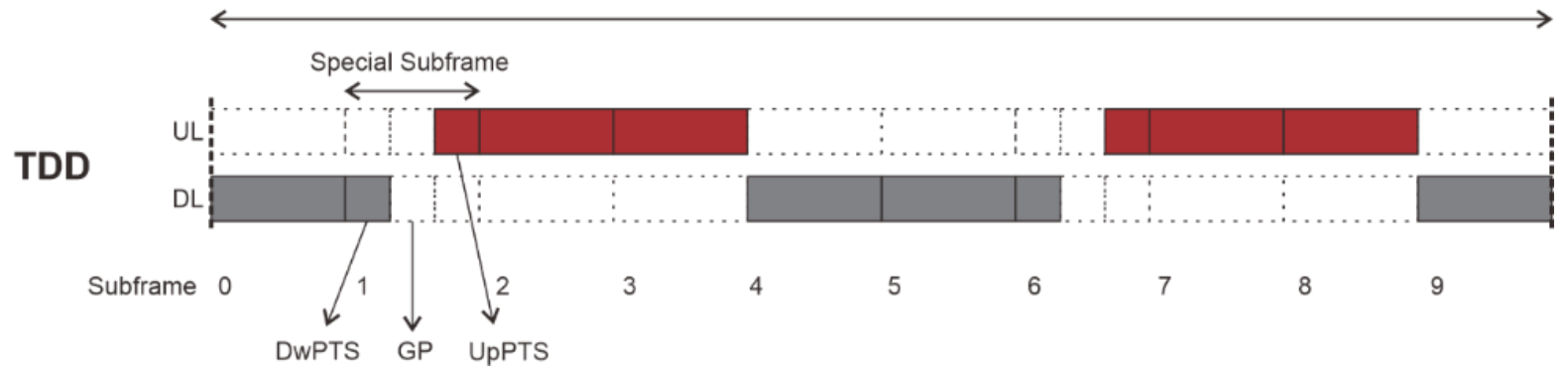

Gambar 1. Skema Time Division Duplexing [5]

Pada skema TDD yang ditunjukkan oleh Gambar 1 subframe dialokasikan untuk downlink transmission, uplink transmission, dan juga dialokasikan untuk special subframe yang berguna untuk trigger dari downlink transmission menuju uplink transmission. Special subframe tidak dibutuhkan saat peralihan dari uplink transmission menuju downlink transmission dikarenakan eNodeB menjadi entitas transmitting utama yang memiliki kemampuan untuk switch dari Rx-Tx tanpa terjadinya delay.

\subsection{Coverage Dimensioning}

Pendekatan dalam hal coverage dibutuhkan untuk mengetahui jumlah perangkat yang dibutuhkan untuk menjangkau cakupan wilayah, dalam proses ini dilakukan kalkulasi terhadap nilai path loss serta pemilihan model propagasi yang digunakan berdasarkan kriteria area studi kasus. Tingkat keakuratan perhitungan salah satunya dipengaruhi dengan pemilihan permodelan propagasi, karena dengan model propagasi kita dapat memprediksi signal propagation behavior.

a. Kalkulasi Maximum Allowable Path Loss (MAPL)

Pada bagian ini dilakukan kalkulasi terhadap nilai dari maximum allowable path loss (MAPL), kalkulasi ini berguna untuk menentukan loss maksimal yang diperbolehkan saat sinyal dipropagasikan dari transmitter (TX) hingga diterima disisi receiver (RX) [6]. Tabel 1 merupakan tabel yang digunakan dalam melakukan estimasi terhadap nilai MAPL. 
Tabel 1. Tabel MAPL

\begin{tabular}{l|l|l}
\hline \multicolumn{3}{c}{ Maximum Allowable Pathloss } \\
\hline Tx & Unit & Formula \\
\hline Max Total Tx Power & $\mathrm{dBm}$ & $a$ \\
\hline Number of Resource Block & & $c$ \\
\hline Subcarrier to Distributed Power & & $d=c \times 12$ \\
\hline Subcarrier Power & $\mathrm{dBm}$ & $\mathrm{e}=a-(10 \times \log d)$ \\
\hline Tx Antenna Gain & $\mathrm{dBi}$ & $g$ \\
\hline Tx Cable Loss & $\mathrm{dB}$ & $h$ \\
\hline EIRP & $\mathrm{dBm}$ & $j=e+g-h$ \\
\hline Rx & $\mathrm{Unit}$ & Formula \\
\hline SINR & $\mathrm{dB}$ & $k$ \\
\hline Rx Noise Figure & $\mathrm{dB}$ & $l$ \\
\hline Thermal Noise & $\mathrm{dBm}$ & $P=K \times T \times B W \times 1000$ \\
\hline Rx Sensitivity & $\mathrm{dBm}$ & $m=k+l-174+(10 \times \log P)$ \\
\hline Rx Body Loss & $\mathrm{dB}$ & $p$ \\
\hline Interference Margin & $\mathrm{dB}$ & $q$ \\
\hline Min Signal Reception Strength & $\mathrm{dBm}$ & $r=m+p+q$ \\
\hline Path Loss dan Shadow Fading Margin & Unit & Formula \\
\hline Penetration Loss & $\mathrm{dB}$ & $s$ \\
\hline Shadow Fading Margin & $\mathrm{dB}$ & $t$ \\
\hline Path Loss dan Shadow Fading Margin & $\mathrm{dB}$ & $u=j-r-s-t$ \\
\hline
\end{tabular}

b. Model Propagasi COST 231 - Hatta

COST sebuah forum Uni Eropa yang bergerak dibidang penelitian ilmiah . COST 231 - Hatta merupakan sebuah model propagasi yang merupakan perluasan dari model propagasi Hatta serta model propagasi Okumura yang bertujuan untuk meningkatkan rentang frekuensi [7]. Model propagasi COST 231 - Hatta untuk urban memiliki persamaan sebagai berikut [8]:

$L u=46.3+33,9 \log f(M H z)-13,82 \log H b+(44.9-6,55 \log H b) \log d$

$a(H r)=(1,1 \log f-0,7) H r-(1,56 \log f-0,8)$

Total $=L u-a(H r)$

Persamaan (1) merupakan persamaan yang digunakan menentukan nilai jarak $d$ dari base station (BS) ke user equipment akibat pengaruh dari nilai path loss $L_{u}$.

c. Kalkulasi Coverage Site

Kalkulasi nilai coverage suatu site bertujuan untuk mengestimasi luas maksimum yang dapat dicakup oleh satu site. Persamaan yang dapat digunakan untuk menetukan coverage site dengan 3 sektor adalah sebagai berikut:

Area $=\frac{9}{8} \sqrt{3} R^{2}$ 


\subsection{Capacity Dimensioning}

Pendekatan dalam hal capacity dibutuhkan untuk mengetahui kemampuan jaringan dalam menyediakan layanan kepada pengguna dengan kualitas yang memenuhi standar. Capacity dimensioning terdiri atas dua prosedur utama, yaitu single site throughput dan total network throughput.

Prosedur yang digunakan dalam melakukan estimasi terhadap nilai single site throughput diantaranya:

a. Kalkulasi Nilai Cell Capacity

Nilai cell capacity berguna untuk mengestimasi kapasitas dari tiap sel. Persamaan yang dapat digunakan adalah:

Cell Capacity $_{(\mathrm{DL})}+\mathrm{CRC}=(168-36-12) \times$ codebits $\times$ coderate $\times \mathrm{N} \times \mathrm{C} \times 1000$

Cell Capacity $_{(\mathrm{UL})}+\mathrm{CRC}=(168-24) \times$ codebits $\times$ coderate $\times \mathrm{N} \times \mathrm{C} \times 1000$

b. Kalkulasi Nilai Capacity per Site

Nilai capacity per site dibutuhkan untuk mengestimasi kapasitas dari tiap site. Persamaan yanng dapat digunakan adalah:

Site Capacity $=$ Cell Average Throughput $_{(D L, U L)} \times 3$

Sedangkan prosedur yang digunakan dalam melakukan estimasi terhadap nilai total network throughput diantaranya:

a. Kalkulasi Nilai Throughput per Session

Nilai throughput per session merupakan nilai throughput berdasarkan tiap layanannya. Persamaan yang dapat digunakan adalah:

$\frac{\text { Throughput }}{\text { Session }}=$ bearer rate $\times$ PPP session time $\times$ PPP session duty rasio $\times[1 /(1-$ BLER $)]$

b. Kalkulasi Nilai Single User Throughput

Pada dasarnya nilai single user throughput adalah penjumlahan untuk setiap layanannya. Persamaan yang dapat digunakan adalah:

SUT $=\frac{\left[\sum\left(\frac{\text { Throughput }}{\text { Session }}\right) \times \text { BHSA } \times \text { PenetrationRatio } \times(1+\text { PAR })\right]}{3600}$

c. Kalkulasi Nilai Total Network Throughput (IP Layer)

Diperoleh dengan mengalikan nilai single user throughput dengan total pengguna layanan. Persamaan yang dapat digunakan adalah:

$\mathrm{TNT}_{(\mathrm{DL}, \mathrm{UL})}=$ Total User Number $\times \mathrm{SUT}_{(\mathrm{DL}, \mathrm{UL})}$

d. Transfer IP Layer Throughput ke MAC Layer Throughput

Dengan terdapatnya pengurangan header pada MAC layer, maka dilakukan konversi nilai yang diperoleh pada IP layer throughput. Persamaan yang dapat digunakan adalah: 
MAC Layer Throughput $=$ IP Layer Throughput $/ 98,04 \%$

e. Kalkulasi Jumlah Transmitter

Jumlah site dapat diperoleh dengan membandingkan nilai total network throughput pada MAC layer dengan site capacity. Persamaan yang dapat digunakan adalah:

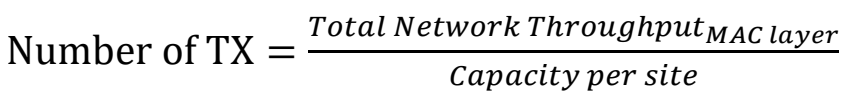

2.4 Parameter Analisa

a. Throughput

Merupakan jumlah aktual data yang berhasil dikirim atau diterima dalam sebuah komunikasi.

b. Reference Signal Received Power (RSRP)

Merupakan daya reference sinyal rata-rata untuk tiap resource element yang terukur [9]. RSRP mengukur daya sinyal lebih baik dari sektor tertentu karena berpotensi meniadakan noise dari sektor lainya. Persamaan yang digunakan untuk mencari nilai RSRP adalah sebagai berikut:

$\operatorname{RSRP}_{(\mathrm{dBm})}=\operatorname{RSSI}_{(\mathrm{dBm})}-10 \times \log (12 \times N)$

c. Received Signal Strength Indicator (RSSI)

Merupakan keseluruhan daya sinyal yang diterima termasuk interferensi, dan daya dari sel lain [10]. RSSI mengukur daya keseluruhan resource block yang mengandung sinyal reference.

$R S S I=$ noise + serving cell power + interference power

d. Carrier-to-Interference plus Noise Ratio (CINR)

Merupakan perbandingan antara daya carrier sinyal RF yang melindungi sinyal informasi dengan keseluruhan daya sinyal interferensi dan noise.

e. Block Error Rate

Mendefinisikan rasio antara tingkat kesalahan block yang diterima dengan total block keseluruhan yang dikirimkan.

\section{Perencanaan Jaringan}

\subsection{Model Perencanaan}

Perencanaan jaringan TD-LTE Advanced dilakukan dengan menggunakan dua buah frekuensi seperti yang tertera pada Gambar 2.

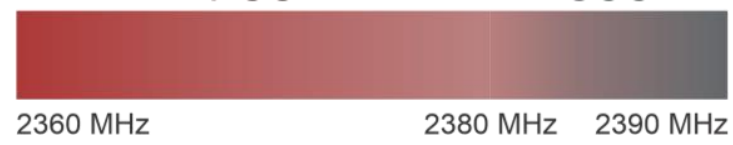

Gambar 2. Skenario Letak Frekuensi 
Skema yang dilakukan adalah dengan menggunakan dua buah frekuensi di antaranya dengan bandwidth $20 \mathrm{MHz}$ yang terletak pada frekuensi $2360-2380 \mathrm{MHz}$ dan frekuensi lainya dengan bandwidth $10 \mathrm{MHz}$ yang terletak pada frekuensi 2380-2390 MHz.

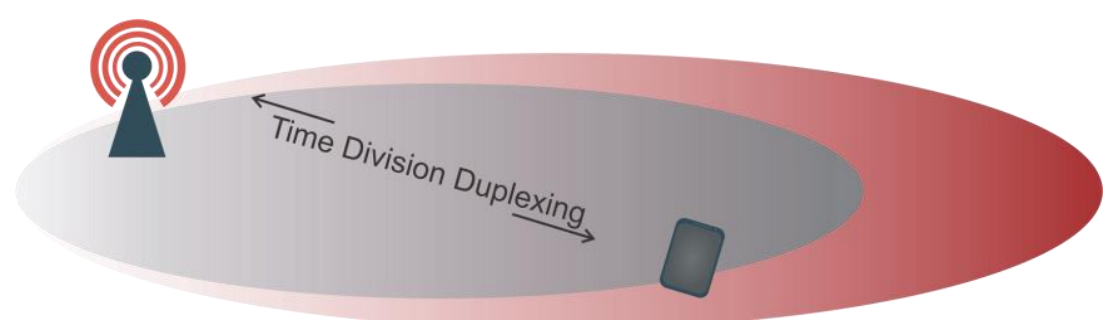

Gambar 3. Permodelan TD-LTE Advanced

Pada simulasi perencanaan jaringan LTE Advanced ini menggunakan metode time division duplexing (TDD) seperti yang tertera pada Gambar 3 .

\subsection{Spesifikasi Sistem}

Spesifikasi sistem yang digunakan pada perencanaan TD-LTE Advanced terdapat pada Tabel 2 berikut ini.

Tabel 2. Spesifikasi TD-LTE Advanced

\begin{tabular}{|c|c|c|c|c|}
\hline Spesifikasi & \multicolumn{2}{|c|}{ Sel A } & \multicolumn{2}{|c|}{ Sel B } \\
\hline Frekuensi & \multicolumn{2}{|c|}{$2360-2380 \mathrm{MHz}$} & \multicolumn{2}{|c|}{$2380-2390 \mathrm{MHz}$} \\
\hline Bandwidth & \multicolumn{2}{|c|}{$20 \mathrm{MHz}$} & \multicolumn{2}{|c|}{$10 \mathrm{MHz}$} \\
\hline \multirow[t]{2}{*}{ Resource Block (RB) } & \multirow{2}{*}{100} & $\mathrm{DL}=60$ & \multirow{2}{*}{50} & $\mathrm{DL}=30$ \\
\hline & & $\mathrm{UL}=20$ & & $\mathrm{UL}=10$ \\
\hline Model Propagasi & \multicolumn{4}{|c|}{ Cost-231 Hatta } \\
\hline Duplexing & \multicolumn{4}{|c|}{ Time Division Duplex (TDD) } \\
\hline Konfigurasi TDD & \multicolumn{4}{|c|}{ Konfigurasi 2} \\
\hline MIMO TRX & \multicolumn{4}{|c|}{$4 \times 4$} \\
\hline
\end{tabular}

\subsection{Skema Perencanaan}

Pada Gambar 4 berikut ini merupakan diagram alir yang menjelaskan tahapan yang dilakukan saat perencanaan TD-LTE Advanced. Lokasi studi kasus yang digunakan dalam penelitian ini berada di Kota Bandung. Pemilihan lokasi studi kasus ini dikarenakan Kota Bandung menjadi salah satu kota dengan tingkat populasi terbanyak di Jawa Barat. Langkah yang ditempuh dalam melakukan perencanaan jaringan TD-LTE Advanced dengan melakukan kalkulasi terhadap capacity dimensioning serta coverage dimensioning. Hasil yang diperoleh dari kalkulasi digunakan sebagai acuan saat melakukan simulasi perencanaan. 


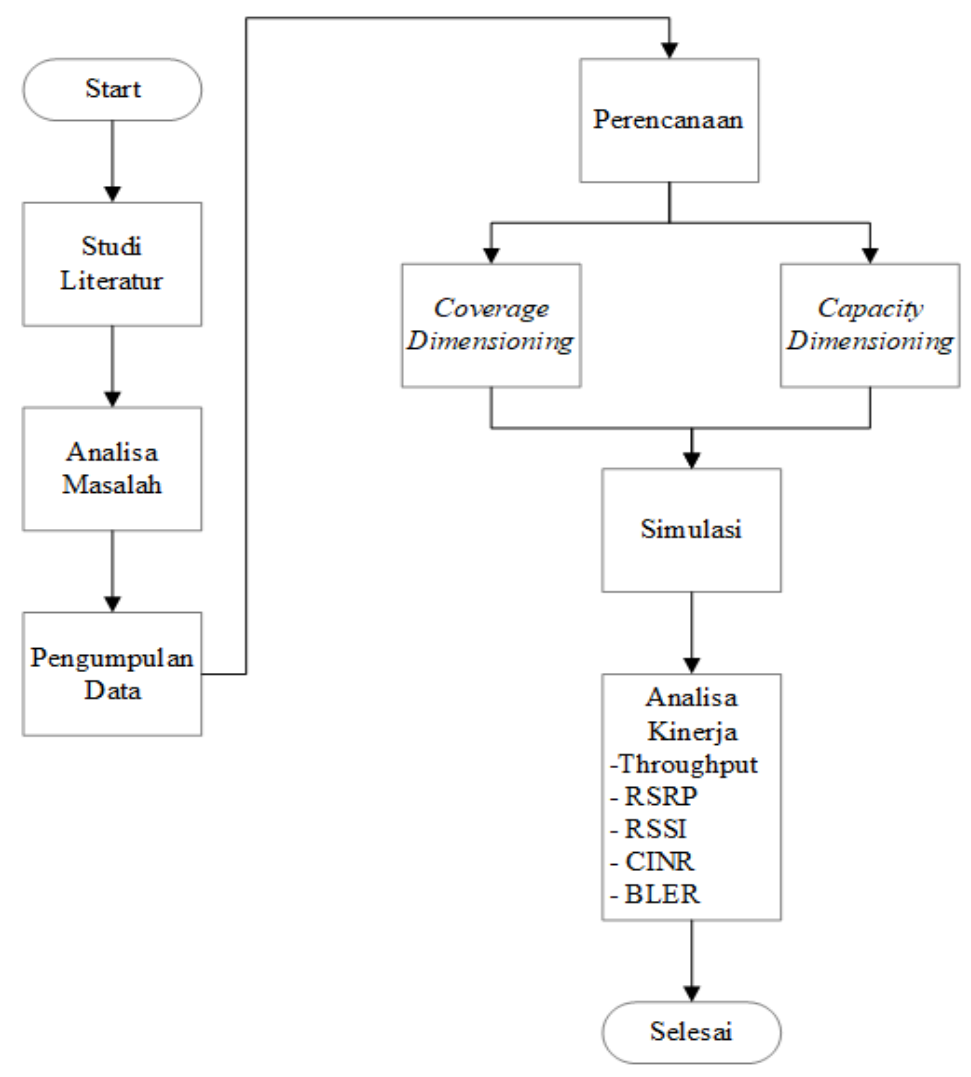

Gambar 4. Diagram Alir Perencanaan

\subsection{Skema Coverage Dimensioning (20 MHz)}

a. Kalkulasi Nilai MAPL

Nilai maximum pathloss dengan bandwidth $20 \mathrm{MHz}$ dijabarkan pada Tabel 3 berikut.

Tabel 3. Kalkulasi Nilai MAPL Bandwidth $20 \mathrm{MHz}$

\begin{tabular}{|c|c|c|c|}
\hline \multicolumn{4}{|c|}{ Maximum Allowable Pathloss } \\
\hline Tx & Unit & Formula & Scale \\
\hline Max Total Tx Power & $\mathrm{dBm}$ & $a$ & 46 \\
\hline Number of Resource Block & & c & 60 \\
\hline Subcarrier to Distributed Power & & $d=c \times 12$ & 720 \\
\hline Subcarrier Power & $\mathrm{dBm}$ & $\mathrm{e}=a-(10 \times \log d)$ & 17,43 \\
\hline Tx Antenna Gain & $\mathrm{dBi}$ & $g$ & 18 \\
\hline Tx Cable Loss & $d B$ & $h$ & 0.5 \\
\hline EIRP & $\mathrm{dBm}$ & $j=e+g-h$ & 34,93 \\
\hline $\mathbf{R x}$ & Unit & Formula & Scale \\
\hline SINR & $\mathrm{dB}$ & $k$ & -9 \\
\hline Rx Noise Figure & $\mathrm{dB}$ & $l$ & 7 \\
\hline Thermal Noise & $\mathrm{dBm}$ & $\begin{array}{l}P=10 \times \log (K \times T \times B W \times 1000) \\
\text { dengan } \\
K=1.38 \times 10^{-23} J^{-1} \\
T=300 K \\
B W=15000 \mathrm{~Hz}\end{array}$ & $-132,07$ \\
\hline Rx Sensitivity & $\mathrm{dBm}$ & $m=k+l-174+(10 \times \log P)$ & $-134,07$ \\
\hline
\end{tabular}




\begin{tabular}{l|l|l|l}
\hline \multicolumn{4}{c}{ Maximum Allowable Pathloss } \\
\hline Rx Body Loss & $\mathrm{dB}$ & $p$ & 0 \\
\hline Interference Margin & $\mathrm{dB}$ & $q$ & 4 \\
\hline Min Signal Reception Strength & $\mathrm{dBm}$ & $r=m+p+q$ & $-130,07$ \\
\hline $\begin{array}{l}\text { Path Loss } \\
\text { dan }\end{array}$ & Unit & Formula & Scale \\
\hline Shadow Fading Margin & $\mathrm{dB}$ & $s$ & 16 \\
\hline Penetration Loss & $\mathrm{dB}$ & $t$ & 8 \\
\hline Phadow Fading Margin & $\mathrm{dB}$ & $u=j-r-s-t$ & 141 \\
\hline
\end{tabular}

b. Kalkulasi Nilai Model Propagasi COST 231-Hatta Bandwidth $20 \mathrm{MHz}$

Dengan menggunakan Persamaan 1 hingga Persamaan 3 dapat diperoleh nilai model propagasi COST 231-Hatta untuk bandwidth $20 \mathrm{MHz}$.

DL:

$L u=46,3+33,9 \log (2360)-13,82 \log (30)+(44,9-6,55 \log (30)) \log d$

$L u=140,23+(35,22 \log d)$

$a(H r)=(1,1 \log (2360)-0,7) 1,5-(1,56 \log (2360)-0,8)$

$a(H r)=0,04$

Total $=\mathrm{Lu}-a(\mathrm{Hr})$

$141=140,23+(35,22 \log d)-0,04$

$d=1,04 \mathrm{Km}$

c. Kalkulasi Nilai Coverage Site

Dengan menggunakan Persamaan 4 dapat diperoleh nilai coverage site dengan bandwidth $20 \mathrm{MHz}$. Jumlah transmitter yang didapat, dipaparkan pada Tabel 4.

Tabel 4. Nilai Coverage Site

\begin{tabular}{c|l|l|c}
\hline $\mathbf{d}(\mathbf{K m})$ & Coverage Site $\left(\mathbf{K m}^{2}\right)$ & Tx Calculation & Total Tx \\
\hline \multirow{2}{*}{1,04} & Area $=\frac{9}{8} \sqrt{3} \times 1,04^{2}$ & Site $=\frac{167,7}{2,11}$ & \multirow{8}{80}{} \\
& Area $=2,11$ & Site $=79,48$ & \\
\hline
\end{tabular}

\subsection{Skema Capacity Dimensioning (20 MHz)}

Langkah pertama yang harus ditempuh pada skema capacity dimensioning adalah dengan melakukan kalkulasi terhadap nilai single site throughput.

a. Kalkulasi Nilai Cell Capacity

Dengan menggunakan Persamaan 5 hingga Persamaan 6 dapat diperoleh nilai cell capacity dengan bandwidth $20 \mathrm{MHz}$. Nilai yang didapat, dipaparkan pada Tabel 5 berikut. 
Tabel 5. Kalkulasi Nilai Cell Capacity Bandwidth $20 \mathrm{MHz}$

\begin{tabular}{l|l|l|l}
\hline \multicolumn{1}{c|}{ Modulation } & \multicolumn{1}{c|}{$\begin{array}{c}\text { Code } \\
\text { Bit }\end{array}$} & \multicolumn{1}{c}{$\begin{array}{c}\text { DL } \\
\text { Code } \\
\text { Rate } \\
\text { CellCapacity } \\
\text { (bps) }\end{array}$} \\
\hline QPSK 1/3 & 2 & 0,34 & \multicolumn{1}{c}{$\mathbf{2 0 ~ M H z}$} \\
\hline QPSK 1/2 & 2 & 0,5 & 26879376 \\
\hline QPSK 2/3 & 2 & 0,67 & 36019176 \\
\hline 16 QAM 1/2 & 4 & 0,5 & 53759976 \\
\hline 16 QAM 2/3 & 4 & 0,67 & 72038376 \\
\hline 16 QAM 4/5 & 4 & 0,8 & 86015976 \\
\hline 64 QAM 1/2 & 6 & 0,5 & 80639976 \\
\hline 64 QAM 2/3 & 6 & 0,67 & 108057576 \\
\hline
\end{tabular}

b. Kalkulasi Cell Average Throughput

Dengan mengalikan nilai SINR probability dengan cell capacity dapat diperoleh nilai cell average throughput dengan bandwidth $20 \mathrm{MHz}$. Nilai cell average throughput yang didapat, dipaparkan pada Tabel 6.

Tabel 6. Kalkulasi Nilai Cell Average Throughput Bandwidth $20 \mathrm{MHz}$

\begin{tabular}{l|l|l|l}
\hline \multicolumn{1}{c|}{ Modulation } & \multicolumn{1}{|c|}{$\begin{array}{c}\text { SINR } \\
\text { Probability }\end{array}$} & \multicolumn{1}{c}{$\begin{array}{c}\text { DL } \\
\text { CellCapacity (Kbps) }\end{array}$} & \multicolumn{1}{c}{$\begin{array}{c}\text { CellAverage } \\
\text { Throughput (Kbps) } \\
\mathbf{2 0 ~ M H z}\end{array}$} \\
\hline QPSK 1/3 & 0,28 & 18278,38 & 5117,95 \\
\hline QPSK 1/2 & 0,25 & 26879,98 & 6720 \\
\hline QPSK 2/3 & 0,17 & 36019,18 & 6123,27 \\
\hline 16 QAM 1/2 & 0,13 & 53759,98 & 6988,8 \\
\hline 16 QAM 2/3 & 0,1 & 72038,38 & 7203,84 \\
\hline 16 QAM 4/5 & 0,05 & 86015,98 & 4300,8 \\
\hline 64 QAM 1/2 & 0,01 & 80639,98 & 806,4 \\
\hline 64 QAM 2/3 & 0,01 & 108057,58 & 1080,58 \\
\hline \multicolumn{2}{c|}{ Cell Average Throughput } & & $\mathbf{3 8 3 4 1 , 6 4}$ \\
\hline
\end{tabular}

c. Kalkulasi Capacity per Site

Dengan menggunakan Persamaan 7 dapat diperoleh nilai capacity per site. Nilai capacity per site yang didapat, dipaparkan pada Tabel 7.

Tabel 7. Kalkulasi Nilai Capacity per Site Bandwidth $20 \mathrm{MHz}$

\begin{tabular}{c|c}
\hline DL Cell Average throughput & DL Capacity per Site \\
(Kbps) & (Kbps) \\
$\mathbf{2 0 ~ M H z}$ & $\mathbf{2 0 ~ M H z}$ \\
\hline 38341,64 & 115024,92 \\
\hline
\end{tabular}


Setelah dilakukan kalkulasi terhadap nilai single site throughput, langkah yang ditempuh selanjutnya adalah melakukan kalkulasi terhadap nilai total network throughput.

a. Kalkulasi Throughput per Session

Dengan menggunakan Persamaan 8 dapat diperoleh nilai throughput per session. Nilai throughput per session yang didapat, dipaparkan pada Tabel 8.

Tabel 8. Kalkulasi Nilai Throughput per Session

\begin{tabular}{l|l|l|l|l|l}
\hline \multirow{2}{*}{$\begin{array}{c}\text { Traffic } \\
\text { Parameter }\end{array}$} & \multicolumn{1}{|c|}{$\begin{array}{c}\text { Dearer } \\
\text { Rate }\end{array}$} & $\begin{array}{c}\text { PPP } \\
\text { Session } \\
\text { Time }\end{array}$ & $\begin{array}{c}\text { PPP } \\
\text { Session } \\
\text { Duty } \\
\text { Ration }\end{array}$ & BLER & \multicolumn{1}{c}{ DL } \\
\hline VoIP & 26,9 & 80 & 0,4 & 0,01 & 869,5 \\
\hline Video Phone & 62,53 & 70 & 1 & 0,01 & 4421,32 \\
\hline $\begin{array}{l}\text { Video } \\
\text { Conference }\end{array}$ & 62,53 & 1800 & 1 & 0,01 & 113690,91 \\
\hline RT Gaming & 125,06 & 1800 & 0,4 & 0,01 & 90952,73 \\
\hline Streaming Media & 250,11 & 3600 & 0,95 & 0,01 & 864016,37 \\
\hline IMS Signaling & 15,63 & 7 & 0,2 & 0,01 & 22,11 \\
\hline Web Browsing & 250,11 & 1800 & 0,05 & 0,01 & 22737,28 \\
\hline File Transfer & 750,34 & 600 & 1 & 0,01 & 454751,52 \\
\hline Email & 750,34 & 15 & 1 & 0,01 & 11368,79 \\
\hline P2P File & 750,34 & 1200 & 1 & 0,01 & 909503,04 \\
\hline
\end{tabular}

b. Kalkulasi Single User Throughput (IP Layer)

Dengan menggunakan Persamaan 9 dapat diperoleh nilai single user throughput pada IP layer. Nilai single user throughput yang didapat, dipaparkan pada Tabel 9.

Tabel 9. Kalkulasi Nilai Single User Throughput (IP Layer)

\begin{tabular}{l|l|l|l|l}
\hline \multirow{2}{*}{$\begin{array}{c}\text { Traffic } \\
\text { Parameter }\end{array}$} & \multicolumn{1}{|c|}{ DL } & \multicolumn{2}{c|}{ Urban } & \multicolumn{1}{c}{ DL } \\
\cline { 2 - 5 } & $\begin{array}{c}\text { Throughput } \\
\text { (Kession }\end{array}$ & \multicolumn{1}{|c|}{ BHSA } & \multicolumn{1}{|c}{ Penetration } & \multicolumn{1}{c}{$\begin{array}{c}\text { Single User Throughput } \\
\text { (Kbps) }\end{array}$} \\
\hline VoIP & 869,5 & 1,3 & 1 & 1356,42 \\
\hline Video Phone & 4421,32 & 0,16 & 0,2 & 169,78 \\
\hline $\begin{array}{l}\text { Video } \\
\text { Conference }\end{array}$ & 113690,91 & 0,15 & 0,15 & 3069,66 \\
\hline RT Gaming & 90952,73 & 0,2 & 0,2 & 4365,74 \\
\hline $\begin{array}{l}\text { Streaming } \\
\text { Media }\end{array}$ & 864016,37 & 0,15 & 0,15 & 23328,45 \\
\hline IMS Signaling & 22,11 & 4 & 0,3 & 31,84 \\
\hline Web Browsing & 22737,28 & 0,4 & 1 & 10913,9 \\
\hline File Transfer & 454751,52 & 0,2 & 0,2 & 21828,08 \\
\hline Email & 11368,79 & 0,3 & 0,1 & 409,28 \\
\hline P2P File & 909503,04 & 0,3 & 0,2 & 65484,22 \\
\hline
\end{tabular}


c. Kalkulasi Total Network Throughput (IP Layer)

Dengan menggunakan Persamaan 10 dapat diperoleh nilai total network throughput pada IP layer. Hasil total network throughput yang didapat, dipaparkan pada Tabel 10.

Tabel 10. Kalkulasi Nilai Total Network Throughput (IP Layer)

\begin{tabular}{|c|c|c|c|}
\hline \multicolumn{2}{|c|}{ Total Target user } & $\begin{array}{c}\text { Single User Throughput } \\
\text { (Kbps) }\end{array}$ & $\begin{array}{c}\text { Network Throughput (IP) } \\
\text { (Kbps) }\end{array}$ \\
\hline Kota & Jumlah User & DL & DL \\
\hline Bandung & 91055 & 36,38 & 3312580,9 \\
\hline
\end{tabular}

d. Konversi IP Layer Throughput ke MAC Throughput

Dengan menggunakan Persamaan 11 dapat dilakukan konversi nilai throughput pada IP layer menjadi MAC layer. Hasil yang didapat, dipaparkan pada Tabel 11.

Tabel 11. Konversi IP Layer Throughput - MAC Layer Throughput

\begin{tabular}{c|c|c|c}
\hline \multirow{2}{*}{ Kota } & \multirow{2}{*}{$\begin{array}{c}\text { Jumlah } \\
\text { User }\end{array}$} & $\begin{array}{c}\text { Network Throughput (MAC) } \\
\text { (Kbps) }\end{array}$ & $\begin{array}{c}\text { Single Site Throughput (MAC) } \\
\text { (Kbps) }\end{array}$ \\
\cline { 3 - 5 } & & DL & DL \\
\hline Bandung & 91055 & 3380184,6 & 115024,92 \\
\hline
\end{tabular}

e. Kalkulasi Jumlah Transmitter

Dengan menggunakan Persamaan 12 dapat diperoleh jumlah transmitter yang dibutuhkan. Jumlah transmitter yang didapat, dipaparkan pada Tabel 12.

Tabel 12. Kalkulasi Jumlah Transmitter Bandwidth $20 \mathrm{MHz}$

\begin{tabular}{c|c|c|c}
\hline $\begin{array}{c}\text { Network Throughput (MAC) } \\
\text { (Kbps) }\end{array}$ & $\begin{array}{c}\text { Capacity per Site (MAC) } \\
\text { (Kbps) }\end{array}$ & Tx Calculation & \multirow{2}{*}{ Total Tx } \\
\hline DL & DL & DL & \\
\hline 3380184,6 & 115024,92 & 29,39 & 30 \\
\hline
\end{tabular}

\subsection{Pemilihan Jumlah Transmitter}

Pemilihan jumlah transmitter yang digunakan akan dilakukan berdasarkan kalkulasi jumlah transmitter yang terbanyak dengan asumsi, bahwa dengan dipilihnya jumlah transmitter terbanyak maka dapat memenuhi kebutuhan baik dari segi coverage ataupun capacity. Pada Tabel 13 berikut ini tertera rangkuman jumlah transmitter hasil dari coverage dan capacity dimensioning.

Tabel 13. Jumlah Transmitter

\begin{tabular}{c|l|c|l|c|c}
\hline \multirow{2}{*}{ Kalkulasi } & \multicolumn{2}{|c|}{ Coverage Dimensioning } & \multicolumn{2}{c|}{ Capacity Dimensioning } & \multirow{2}{*}{ Acuan } \\
\cline { 2 - 5 } & $\mathbf{2 0} \mathbf{~ M H z}$ & $\mathbf{1 0} \mathbf{~ M H z}$ & $\mathbf{2 0} \mathbf{~ M H z}$ & $\mathbf{1 0} \mathbf{~ M H z}$ & \\
\hline Jumlah Tx & 80 & 52 & 30 & 59 & $\mathbf{8 0}$ \\
\hline
\end{tabular}




\section{Hasil dan Analisa}

Pada bagian ini dipaparkan hasil yang diperoleh dari pengujian terhadap perencanaan jaringan TD-LTE Advanced dengan area studi kasus adalah Kota Bandung.

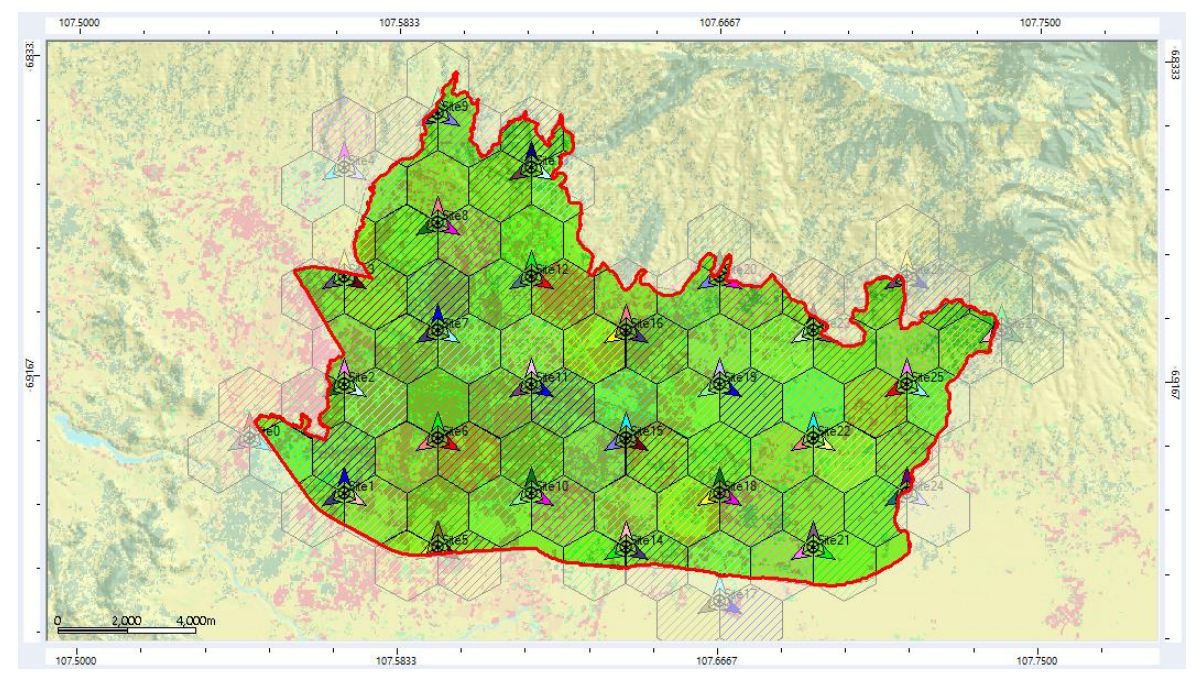

Gambar 5. Perencanaan TD-LTE Advanced

Pada Gambar 5 menunjukkan hasil simulasi diperoleh jumlah transmitter yang digunakan pada perencanaan TD-LTE Advanced sebanyak 84 transmitter dengan pembagian menjadi 3 sektor sehingga jumlah transmitter yang digunakan pada simulasi mendekati jumlah transmitter yang telah diperhitungkan sebelumnya.

\subsection{Parameter Throughput}

Gambar 6 menunjukkan hasil simulasi yang diperoleh dari pengujian terhadap parameter throughput.

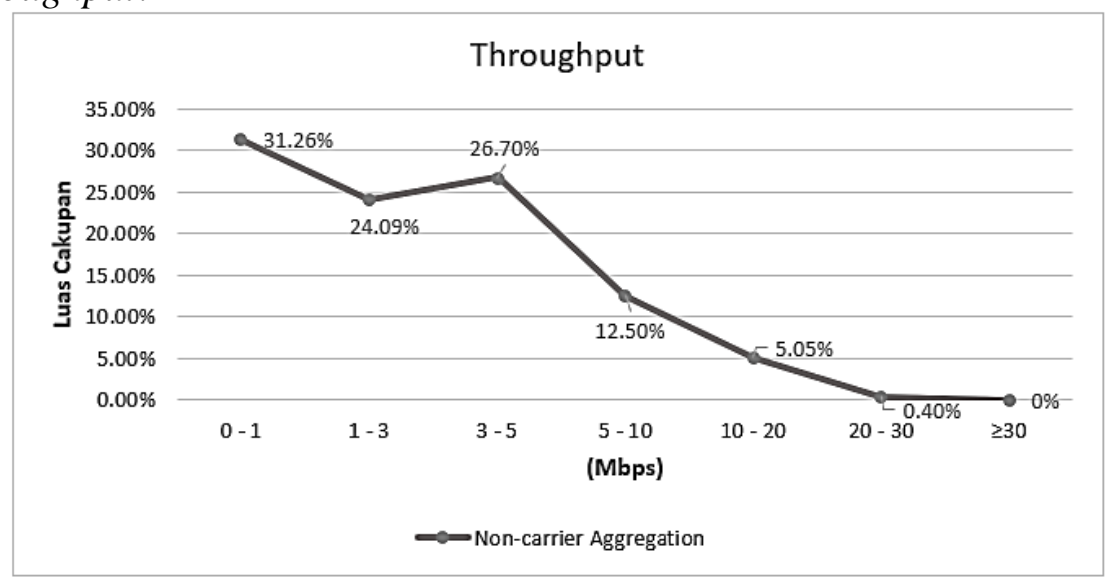

Gambar 6. Parameter Throughput

Pada Gambar 6 menunjukkan 31,26\% luas cakupan memiliki nilai throughput $<1 \mathrm{Mbps,}$ sementara throughput maksimum yang diperoleh pada rentang nilai 20-30 Mbps hanya memiliki cakupan sebesar $0,4 \%$. Sehingga diketahui bahwa pada simulasi ini TD-LTE tidak mampu menghasilkan throughput yang cukup tinggi hal ini ditunjukkan dengan semakin menurunya nilai throughput yang diperoleh. Nilai throughput dengan kinerja terbaik pada simulasi TD-LTE Advanced berkisar pada rentang 3-5 Mbps yang memiliki luas sebesar $26,70 \%$ dari total luas cakupan. Sementara nilai rata-rata throughput yang diperoleh sebesar 


\section{3,5 Mbps.}

\subsection{Parameter RSRP}

Gambar 7 menunjukkan hasil simulasi yang diperoleh dari pengujian terhadap parameter RSRP.

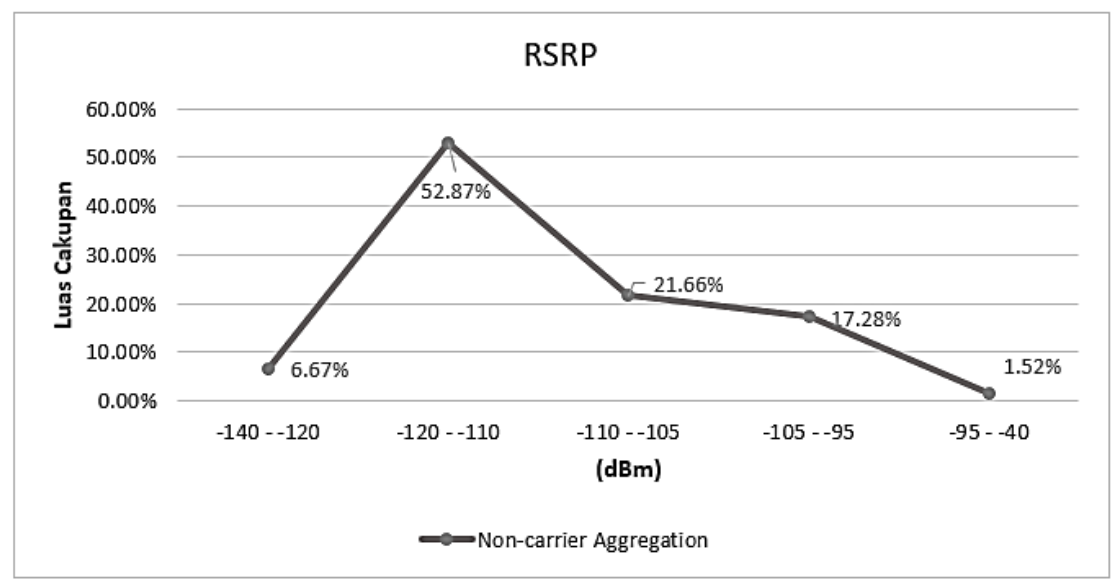

Gambar 7. Parameter RSRP

Pada Gambar 7 menunjukkan rentang nilai RSRP dengan kinerja berurut dari nilai minimum hingga optimum. Dari Gambar 7 diketahui bahwa nilai RSRP terendah dengan nilai $<-120$ dBM memiliki luas sebesar $6,67 \%$ dari total luas cakupan, nilai RSRP terbaik dengan nilai $\geq$ $95 \mathrm{dBm}$ hanya memiliki luas sebesar $1,52 \%$ dari total luas cakupan. Sementara nilai RSRP dominan terdapat pada rentang $-120 \mathrm{dBm}$ hingga $-110 \mathrm{dBm}$ yang memiliki luas sebesar $52,87 \%$ dari total luas cakupan dan dihasilkan nilai rata-rata RSRP yang diperoleh sebesar $-110 \mathrm{dBm}$.

\subsection{Parameter RSSI}

Gambar 8 menunjukkan hasil simulasi yang diperoleh dari pengujian terhadap parameter RSSI.

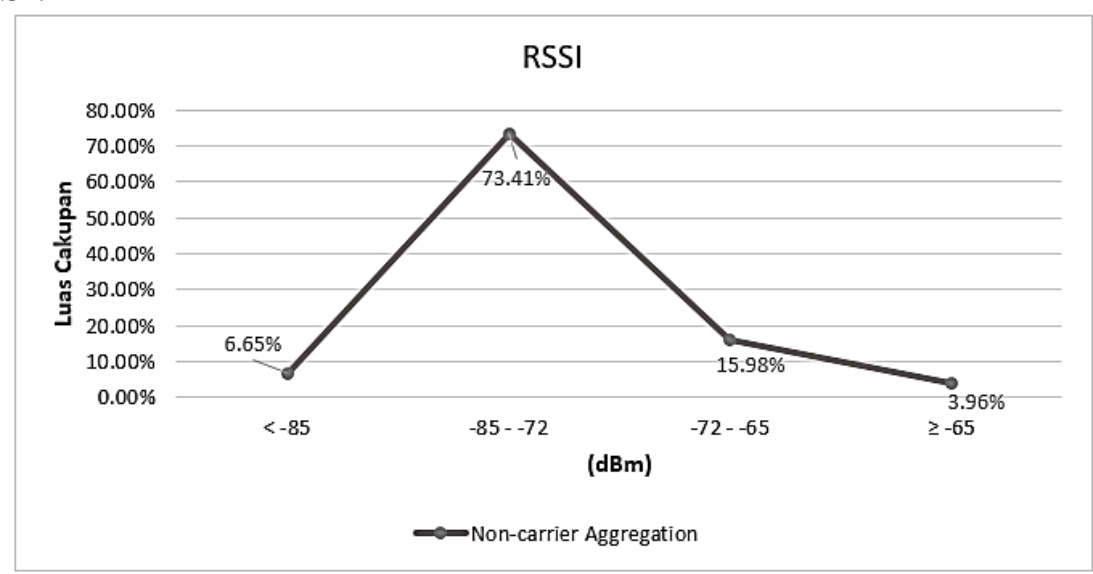

Gambar 8. Parameter RSSI

Pada Gambar 8 menunjukkan rentang nilai RSSI dengan kinerja berurut dari nilai minimum hingga optimum. Dari Gambar 8 diketahui bahwa nilai RSSI terendah dengan nilai $<-85 \mathrm{dBm}$ memiliki luas $6,65 \%$ dari total luas, nilai RSSI paling dominan berada pada rentang -85 hingga $-72 \mathrm{dBm}$ yang memiliki luas hingga 73,41\% dari total luas cakupan, dan nilai RSSI terbaik dengan nilai $\geq-65 \mathrm{dBm}$ hanya memiliki cakupan sebesar $3.96 \%$. Nilai rata-rata RSSI yang 
diperoleh dari simulasi sebesar $-72.36 \mathrm{dBm}$.

\subsection{Parameter CINR}

Gambar 9 menunjukkan hasil simulasi yang diperoleh dari pengujian terhadap parameter CINR.

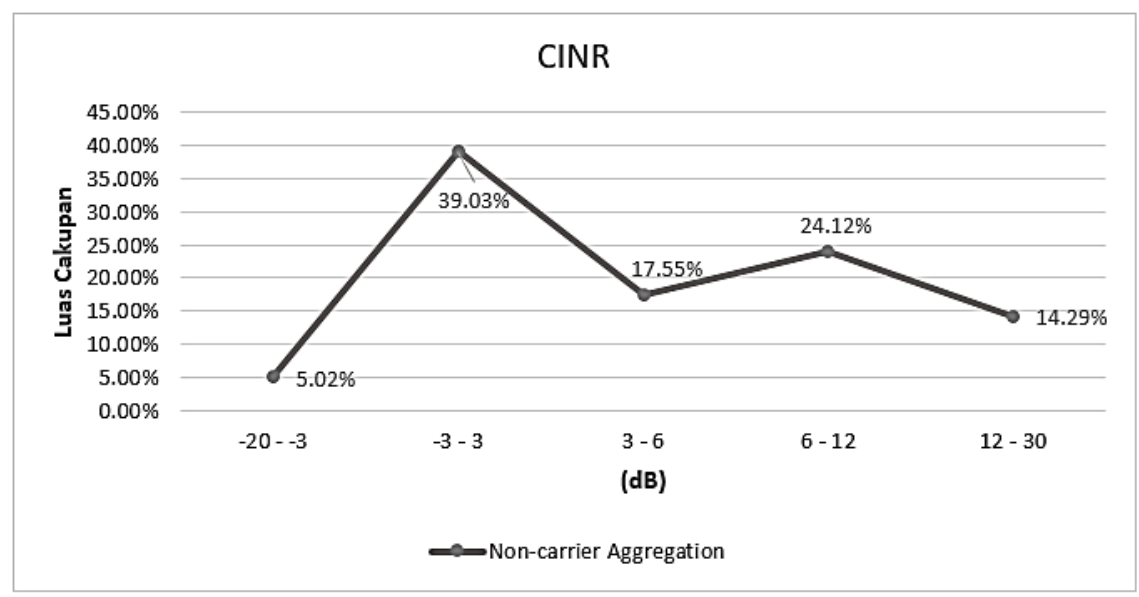

Gambar 9. Parameter CINR

Pada Gambar 9 menunjukkan rentang nilai CINR dengan kinerja berurut dari nilai minimum hingga optimum. Dari Gambar 9 diketahui bahwa nilai CINR terendah dengan nilai $<-3 \mathrm{~dB}$ memiliki luas 5,02\% dari total luas cakupan, nilai CINR paling dominan berada pada rentang -3 dB hingga $3 \mathrm{~dB}$ yang memiliki luas hingga 39,03\% dari total luas cakupan, dan nilai CINR terbaik dengan nilai $\geq 12 \mathrm{~dB}$ memiliki luas sebesar $14.29 \%$ dari total luas cakupan. Sementara nilai rata-rata CINR yang diperoleh sebesar $4.81 \mathrm{~dB}$ sehingga dapat disimpulkan bahwa walaupun dengan menggunakan dua buah sel yang bekerja pada rentang frekuensi yang berdekatan nilai interferensi dan noise yang mengganggu sinyal informasi terbilang cukup rendah. Hal ini diketahui karena daya sinyal informasi 3,03× lebih kuat bila dibandingkan dengan daya interferensi dan noise yang terjadi.

\subsection{Parameter BLER}

Gambar 10 menunjukkan hasil simulasi yang diperoleh dari pengujian terhadap parameter BLER.

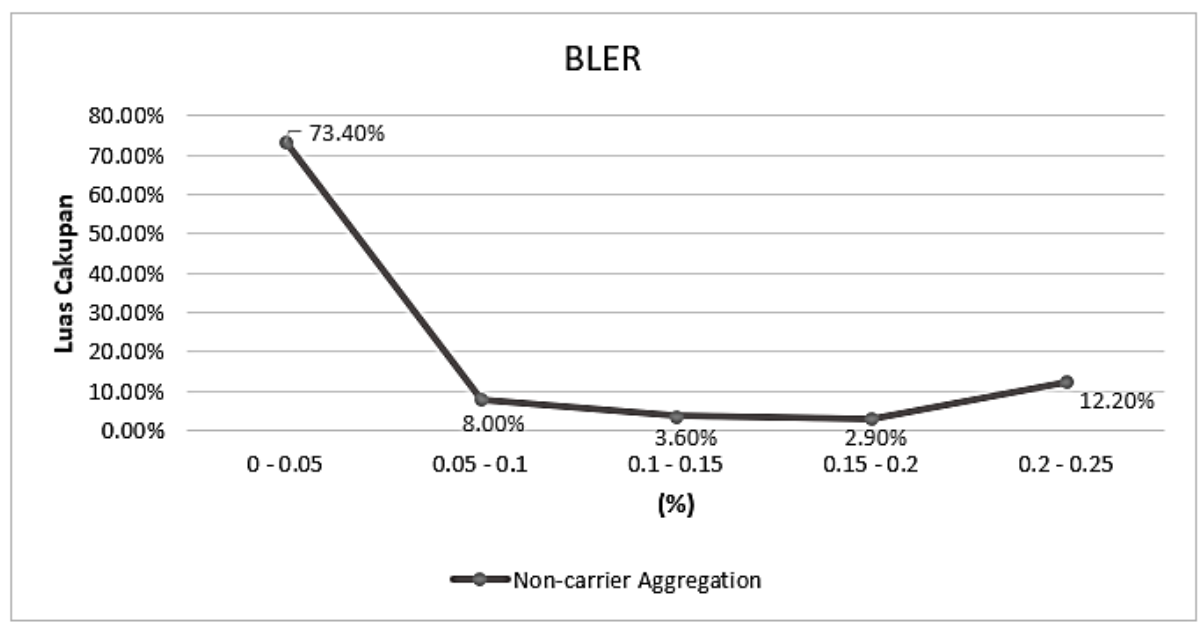

Gambar 10. Parameter BLER 
Pada Gambar 10 menunjukkan rentang nilai BLER dengan kinerja berurut dari nilai maksimum hingga minimum. Dari Gambar 10 diketahui bahwa nilai BLER maksimum yang diperoleh dengan nilai $<0,05 \%$ memiliki luas sebesar $73,40 \%$ dari total luas cakupan nilai ini juga menjadi nilai dengan kinerja yang paling dominan, sementara nilai BLER minimum dengan nilai $>0,2 \%$ memiliki luas sebesar $12,20 \%$ dari total luas cakupan. Pada simulasi ini nilai ratarata BLER yang diperoleh sebesar $0.07 \%$.

\subsection{Rekomendasi}

Dengan demikian rangkuman kinerja yang didapat dari simulasi TD-LTE Advanced dengan area studi kasus Kota Bandung dapat dilihat pada Tabel 14.

Tabel 14. Rangkuman Kinerja Sistem

\begin{tabular}{|c|c|c|}
\hline Nilai Rata-Rata Parameter & Nilai & Kesimpulan \\
\hline Throughput & 3,5 Mbps & \multirow{5}{*}{$\begin{array}{l}\text { Kurang cocok } \\
\text { diterapkan pada } \\
\text { daerah high demand } \\
\text { akibat rendahnya } \\
\text { nilai throughput. }\end{array}$} \\
\hline RSRP & $-110,8 \mathrm{dBm}$ & \\
\hline RSSI & $-72,36 \mathrm{dBm}$ & \\
\hline CINR & $4,81 \mathrm{~dB}$ & \\
\hline BLER & $0,07 \%$ & \\
\hline
\end{tabular}

Walaupun memiliki nilai CINR yang baik dengan nilai rata-rata sebesar 4,81 dB, hasil simulasi pada perencanaan TD-LTE Advanced mendapatkan nilai rata-rata throughput yang cukup kecil yaitu hanya sebesar 3,5 Mbps dengan nilai ini TD-LTE Advanced kurang cocok bila di implementasikan pada daerah yang memiliki demand yang cukup tinggi seperti Kota Bandung. Hal ini disebabkan karena Kota Bandung memiliki cukup banyak sektor perkantoran, industri, moda transportasi yang menjadi indikator penting dalam high demand area.

\section{Kesimpulan}

1. Penggunaan metode duplexing TDD dimana komunikasi dibagi berdasarkan waktu menyebabkan nilai throughput yang dihasilkan cukup rendah, berdasarkan simulasi nilai rata-rata throughput yang dihasilkan sebesar 3,5 Mbps.

2. Penggunaan dua buah frekuensi yang berdekatan akan menyebabkan adjecent channel interference, tetapi berdasarkan simulasi nilai rata-rata CINR yang dihasilkan cukup baik yaitu sebesar 4,81 dB.

3. TD-LTE Advanced kurang cocok bila diimplementasikan pada daerah high demand, dimana data rate menjadi elemen penting.

4. Skema duplexing TDD memiliki keunggulan dalam hal efisiensi spektrum frekuensi hal ini dikarenakan hanya dibutuhkannya frekuensi tunggal. Tetapi akibat dibutuhkanya guard period metode duplexing TDD kurang mampu untuk menghasilkan nilai throughput yang baik.

\section{Daftar Pustaka}

[1] Astély, D., Dahlman, E., Furuskär, A., Jading, Y., Lindström, M., \& Parkvall, S. (2009). LTE: the evolution of mobile broadband. IEEE Communications magazine, 47(4), 4451.

[2] Dalia Abdalla Omer, E., Babiker, A. A., \& Mustafa, N. (2015). LTE FDD vs LTE TDD from a Qos Perspective. IOSR Journal of Electronics and Communication Engineering, 10(21), 2278-2834. 
[3] Chan, P. W., Lo, E. S., Wang, R. R., Au, E. K., Lau, V. K., Cheng, R. S., ... \& Letaief, K. B. (2006). The evolution path of $4 \mathrm{G}$ networks: FDD or TDD?. IEEE Communications Magazine, 44(12), 42-50.

[4] Soehartono, S. E. (2012, October). FDD and TDD comparison for consideration of slot spectrum assignment in Indonesia. In 2012 7th International Conference on Telecommunication Systems, Services, and Applications (TSSA) (pp. 266-269). IEEE.

[5] Yonis, A. Z., Abdullah, M. F. L., \& Ghanim, M. F. (2012). LTE-FDD and LTE-TDD for cellular communications. Proceeding, Progress in.

[6] Chandra, D., Yusnita, S., Aulia, S., \& Ardila, N. Perencanaan Jaringan 4G LTE Dengan Teknologi FDD Pada Frekuensi 1800 MHz Berbasis Cost-231 Hatta Propagation Model di Kota Padang.

[7] ElNashar, A., El-Saidny, M. A., \& Sherif, M. (2014). Design, deployment and performance of 4G-LTE networks: A practical approach. John Wiley \& Sons.

[8] Kurniawan, U. (2008). Pengantar Ilmu Telekomunikasi. Penerbit Informatika.

[9] Cox, C. (2012). An introduction to LTE: LTE, LTE-advanced, SAE and $4 G$ mobile communications. John Wiley \& Sons.

[10] Sauter, M. (2014). From GSM to LTE-advanced: an introduction to mobile networks and mobile broadband. John Wiley \& Sons. 